\title{
PEMEROLEHAN BAHASA ANAK USIA 4 TAHUN KAJIAN SEMANTIK PENYIMPANGAN TUTURAN ANAK
}

\author{
Oktavian Aditya Nugraha \\ STKIP BINA INSAN MANDIRI SURABAYA \\ oktavianaditya@yahoo.co.id
}

\begin{abstract}
Speech deviation by a four-year old child happens because in this age, they are in the process of language mastery after their first language. At least, it is influenced by two factors: physiological and psychological factors. Physiological factor comprises speech production organs such as mouth and brain function. Meanwhile, psychological factor comprises children cognitive development in the process of first language mastery. The objective of this research was to describe the speech deviation of four-year old children by using semantic study which is taken from their language acquisition. The method of collecting data used by the researcher was scrutinizing methods with tapping technique. This research also used an open-ended interview, recording, and documentation. The method of data analysis used in this research covered extra-lingual comparison method which is used to analyze extra-lingual elements such as connecting language problem with things outside the language itself. The result showed that language mastery of four-year old children is in the level or process of language development which later can be completed along with the children are growing up. Deviations found in the speech comprise 12 word deviations which are often spoken by children. The relation of semantical language acquisition of four-year old children is thought to be in the level of development appropriate with their age. Speech deviations found comprise semantic deviation which are incompatible between a word spoken and its reference.
\end{abstract}

Keywords: language acquisition, semantic, speech deviation.

\begin{abstract}
Abstrak
Penyimpangan tuturan yang terjadi pada anak yang berusia 4 tahun terjadi karena pada usia tersebut, anak dalam proses penguasaan bahasa sesudah bahasa pertama dan setidaknya dipengaruhi oleh dua hal, yaitu faktor fisiologis dan psikologis. Faktor fisiologis meliputi organ-organ penghasil tuturan seperti mulut dan fungsi otak. Sementara itu, faktor psikologis meliputi perkembangan kognitif seorang anak dalam proses penguasaan bahasa pertamanya. Tujuan penelitian ini adalah mendeskripsikan penyimpangan tuturan bahasa anak usia 4 tahun dengan kajian semantik yang didapatkan dari pemerolehan bahasanya. Metode pengumpulan data yang digunakan adalah menggunakan metode simak dengan teknik sadap. Teknik lanjutan yang digunakan adalah berupa simak libat cakap, rekam, dan catat. Metode analisis yang digunakan mencakup metode padan ekstralingual yang digunakan untuk menganalisis unsur yang bersifat ekstralingual, seperti menghubungkan masalah bahasa dengan hal yang berada
\end{abstract}


di luar bahasa. Hasil yang diperoleh menunjukkan bahwa penguasaan bahasa anak usia 4 tahun bisa dikatakan dalam taraf atau proses perkembangan bahasa yang nantinya bisa sempurna saat usia bertambah. Penyimpangan yang ditemukan meliputi 12 penyimpangan kata yang sering kali diucapkan oleh anak. Hubungan dengan semantik pemerolehan bahasa anak usia 4 tahun dinilai masih dalam tahap perkembangan sesuai dengan usia mereka. Penyimpangan tuturan yang ditemukan meliputi penyimpangan tuturan di bidang semantik yaitu ketidaksesuaian antara satu kata yang diucapkan dengan acuannya.

Kata Kunci: Pemerolehan Bahasa, Semantik, Penyimpangan Tuturan.

\section{Pendahuluan}

Telah dikukuhkan oleh para ahli bahasa bahwa bahasa sebagai alat komunikasi secara genetis hanya ada pada manusia, tidak terdapat pada makhluk hidup lainnya. Manusia berinteraksi satu dengan yang lain melalui komunikasi dalam bentuk bahasa. Komunikasi tersebut terjadi, baik secara verbal maupun non verbal dengan tulisan, bacaan, dan tanda atau simbol. Berbahasa merupakan proses kompleks. Manusia berkomunikasi lewat bahasa dan memerlukan proses yang berkembang dalam tahap-tahap usianya. Cara manusia bisa memeroleh bahasa sebagai cara berkomunikasi selalu menjadi bahan diskusi yang menarik untuk dibahas sehingga memunculkan banyak teori tentang pemerolehan bahasa. Hal ini lebih rumit dan luas mengingat ada lebih dari seribu bahasa yang ada di seluruh dunia.

Bahasa adalah bentuk aturan atau sistem lambang yang digunakan anak dalam berkomunikasi dan beradaptasi dengan lingkungannya yang dilakukan untuk bertukar gagasan, pikiran, dan emosi. Bahasa bisa diekspresikan melalui bicara dengan mengacu pada simbol verbal. Selain itu bahasa dapat juga diekspresikan melalui tulisan, tanda gestural dan musik. Bahasa juga dapat mencakup aspek komunikasi nonverbal seperti gestikulasi, gestural atau pantomim. Gestikulasi adalah ekspresi gerakan tangan dan lengan untuk menekankan makna wicara. Pantomim adalah sebuah cara komunikasi yang mengubah komunikasi verbal dengan aksi yang mencakup beberapa gestural (ekspresi gerakan yang menggunakan setiap bagian tubuh) dengan makna yang berbeda beda.

Perkembangan komunikasi anak sesungguhnya sudah dimulai sejak dini, pertama-tama dari tangisannya. Usia 3 minggu bayi tersenyum saat ada rangsangan dari luar, misalnya wajah seseorang, tatapan mata, suara dan gelitikan. Proses pemerolehan bahasa merupakan bagian yang penting dalam perkembangan kemampuan bahasa setiap individu. Pemerolehan bahasa atau akuisisi adalah proses yang berlangsung di dalam otak seorang kanak-kanak ketika dia memperoleh bahasa pertamanya atau bahasa ibunya (Chaer, 2003, p. 167). Proses inilah ketika anak dapat menguasai bahasa pertamnya.

Setiap anak mengalami perkembangan bahasa yang berbeda-beda. Namun pada dasarnya setiap anak yang normal mulai berbicara antara umur dua puluh sampai dua puluh delapan bulan. Hal tersebut terjadi karena organ-organ bicara yang dimiliki setiap anak sudah mulai berkembang dan terprogram untuk memperoleh bahasa. Salah satu golongan kosakata yang dikuasai oleh anak adalah golongan kelas kata nomina terutama yang akrab dengan tempat tinggalnya. Sesungguhnya rangsangan bahasa yang diterima oleh kanakkanak tidak teratur. Namun, mereka berupaya memahami sistem-sistem linguistik bahasa pertama sebelum menjangkau usia lima tahun. Dari setiap perbedaan perkembangan bahasa anak yang diperoleh individual anak, dapat dikatan banyak penyimpangan tuturan anak yang diperoleh melalui aktivitas kebahasaan, terutama pada usia dini. Pada hakikatnya 
pemerolehan bahasa khususnya anak usia 4 tahun sudah membentuk kalimat penuh karena dia belum bisa mengatakan lebih dari satu suku kata, hanya bisa mengambil satu kata itu dari keseluruhan kalimat bagi anak sebenarnya (Dardjowidjojo, 2008, p. 246).

Masalah yang akan dikaji dalam penelitian ini adalah penyimpangan bahasa anak usia 4 tahun dari perspektif kajian semantik. Tujuan penelitian ini adalah mendeskripsikan penyimpangan tuturan bahasa anak usia 4 tahun dengan kajian semantik yang didapatkan dari pemerolehan bahasanya.

Penelitian sebelumnya yang dilakukan Ruqayyah (2008) tentang pemerolehan bahasa anak usia 4-6 tahun menyimpulkan adanya "perbedaan bahasa anak dari usia tingkatan tersebut". Penelitian yang dilakukan oleh Budi Santoso (2009) tentang pemerolehan bahasa anak usia 3 tahun dalam lingkup keluarga yang menyimpulkan bahwa "berdasarkan panjang ayat, anak usia tiga tahun, dalam bertutur, pada umumnya mengucapkan kata-kata secara terpenggal. Penguasaan bahasa yang dikuasai anak diperoleh melalui tahapan-tahapan tertentu dan anak umur tiga tahun sudah mampu menyusun kalimat dalam bertutur meskipun masih sangat sederhana dan terbatas dan berdasarkan jumlah ujaran setiap giliran tutur dibuktikan anak tiga tahun dalam bertutur hanya menjawab pertanyaan dari lawan tutur". Titik Milawati (2009) meneliti peran pendidikan anak usia dini dalam mendukung perkembangan bahasa anak. Penelitian ini menghasilkan kesimpulan bahwa perkembangan bahasa anak sangat berpengaruh sejak saat usia dini.

Pemerolehan bahasa atau akuisisi bahasa adalah proses yang berlangsung di dalam otak kanak-kanak ketika memperoleh bahasa ibunya. Pemerolehan bahasa biasanya dibedakan dengan pembelajaran bahasa. Pembelajaran bahasa berkaitan dengan proses-proses yang terjadi pada waktu seorang kanak-kanak mempelajari bahasa kedua setelah dia memperoleh bahasa pertamanya. Jadi, pemerolehan bahasa berkenaan dengan bahasa pertama, sedangkan pembelajaran bahasa berkenaan dengan bahasa kedua (Chaer, 2003, p. 167).

Selama pemerolehan bahasa pertama, Chomsky menyebutkan bahwa ada dua proses yang terjadi. Proses yang dimaksud adalah proses kompetensi dan proses performansi. Kompetensi adalah proses penguasaan tata bahasa (fonologi, morfologi, sintaksis, dan semantik) secara tidak disadari. Kompetensi ini dibawa oleh setiap anak sejak lahir. Meskipun dibawa sejak lahir, kompetensi memerlukan pembinaan sehingga anak-anak memiliki performansi dalam berbahasa. Performansi adalah kemampuan anak menggunakan bahasa untuk berkomunikasi. Performansi terdiri dari dua proses, yaitu proses pemahaman dan proses penerbitan kalimat-kalimat. Proses pemahaman melibatkan kemampuan mengamati atau mempersepsi kalimat-kalimat yang didengar, sedangkan proses penerbitan melibatkan kemampuan menghasilkan kalimat-kalimat sendiri (Chaer 2003, p. 167).

Bahasa mengandung simbol untuk bertukar informasi. Kemampuan berbahasa lebih pada kemampuan yang dapat dilihat alias dinilai. Perkembangan bahasa dan bicara digambarkan sebagai berikut:

a. Bahasa reseptif (masa praverbal): masa mulai tangisan pertama sampai keluar kata pertama. Bayi memproduksi bahasa prelinguistik yang biasanya sesuai dengan pengasuhnya. Bahasa yang semula dikeluarkan adalah cooing atau suara seperti suara "vokal" tertentu (seperti "au" atau "u"). Tahap prelinguistik cooing ini biasanya terdengar pada usia 4-6 minggu.

b. Bahasa ekspresif (masa verbal): kemampuan anak untuk mengeluarkan kata-kata yang berarti (biasanya pada usia 12-18 bulan). Misalnya, kata "mama" atau "papa". 
Selain kedua jenis bahasa tersebut, dikenal pula bahasa visual. Tahap bahasa yang berhubungan dengan emosi ini muncul dalam beberapa minggu setelah kelahiran bayi. Bahasa visual adalah;

a. Usia 4-6 minggu: Bayi "memamerkan" senyum sosial.

b. Usia 2-3 bulan: Bayi mulai memperhatikan orang dewasa yang sedang bicara. Begitu ia berhenti bicara, bayi akan mengeluarkan suara. Ini pada dasaradanya adalah interaksi pada anak, yang merupakan awal dari tahap bicara.

c. Usia 4-5 bulan: Bayi harus terlihat mencari sumber suara.

d. Usia 6-7 bulan: Bayi menikmati permainan, seperti ci luk ba.

e. Usia 9 bulan: Bayi mulai menggunakan tangannya untuk melakukan kegiatan sederhana, seperti melambaikan tangan, sebagai ekspresi interaksi sosial.

f. Usia 9-12 bulan: Bayi memperlihatkan keinginannya pada suatu obyek dengan cara meraih atau menangis bila tidak mendapatkannya.

g. Usia 12 bulan: Bayi mulai menggunakan jarinya untuk menunjuk benda-benda yang diinginkan.

Pemaparan tersebut sebagian dari perkembangan bahasa anak. Bahasa anak akan terus berkembang sesuai dengan usia anak tersebut.

Menurut Verhaar (2008, p. 135) semantik adalah cabang linguistik yang meneliti arti atau makna. Semantik dibagi menjadi semantik gramatikal dan leksikal. Secara gramatikal unsur yang pembawa makna yang terkecil yang bersifat gramatikal adalah morfem, maksudnya konteks ini, morfem terikat seperti afiksasi. Sementara itu, segi leksikal unsur yang dimaksud adalah leksikologi terapan. Hal tersebut mencakup jumlah yang banyak, antara lain: makna dan referensi, denotasi dan konotasi, analisis ekstensional dan analisis intensional.

\section{Metode Penelitian}

Jenis penelitian ini adalah deskripsi kualitatif. Bentuk penelitian menurut Moleong (2005, p. 11) adalah penelitian yang bersumber pada data yang dikumpulkan berupa katakata, gambar, dan bukan angka-angka. Menggambarkan analisis pemerolehan bahasa anak usia 4 tahun, kajian semantik penyimpangan tuturan anak. Penggambaran proses tersebut sesuai dengan fakta-fakta yang tampak. Metode ini merupakan prosedur pemecahan masalah dengan menggambarkan atau melukiskan keadaan subjek dan objek penelitian pada saatnya sekarang bedasarkan fakta yang tampak.

Subjek penelitian ini adalah anak usia dini khususnya anak usia 4 tahun. Objek penelitian ini adalah penyimpangan tuturan anak usia 4 tahun kajian semantik, pemerolehan bahasa anak. Kebahasan yang diucapkan anak usia 4 tahun, akan diteliti dari segi kesalahan semantik.

Data dan sumber data yang dibutuhkan untuk meneliti ini berupa tuturan anak usia dini. Sumber datanya yaitu anak usia dini khususnya 4 tahun. Pengumpulan data menggunakan metode simak, dengan teknik sadap. Teknik lanjutan berupa simak libat cakap, rekam, dan catat. Peneliti mengamati kebahasaan sehari-hari yang dilakukan oleh anak usia 4 tahun. Setelah data rekam didapatkan, kegiatan selanjutnya adalah menyimak dan mencatat hasil rekaman.

Keabsahan data diuji dengan menggunakan kredibilitas. Dalam penelitian kualitatif, hal ini dapat diartikan dengan istilah validitas internal. Pemeriksaan kredibilitas terhadap temuan penelitian berarti mempersoalkan tentang seberapa jauh suatu temuan itu memiliki kebenaran yang dipercaya. Metode yang digunakan untuk analisis data adalah metode padan 
ekstralingual. Metode ini digunakan untuk menganalisis unsur yang bersifat eksralingual, seperti menghubungkan masalah bahasa dengan hal yang berada di luar bahasa (Mahsun, 2007, p. 188-120).

\section{Hasil Dan Pembahasan}

Seorang anak mungkin dapat mengetahui apabila orangtuanya menggunakan bahasa yang berbeda-beda di rumah dan di luar rumah. Dalam pemerolehan bahasa anak, setelah berusia 4 tahun dalam tuturan katanya masih mengalami tuturan yang salah. Penguasaan bahasa anak usia 4 tahun bisa dikatakan dalam taraf atau proses. Kebanyakan anak-anak ini menggunakan bahasa daerah ngoko seperti:

Aku edi $=$ Aku wedi, Moh $a=$ Moh ah, Uan-udan = udan-udan, Alow mandi $=$ Ayo mandi, Byor banyu = Gebyur banyu, Tah mau = Gak mau, Cemplung ember $=$ Nyemplung ember, Ngopo oe = Ngopo kowe, Njipok ewe $=$ Njipok dewe, Njibok.ke $=$ Jipok,ke, Anak kecil mama ya = Anak kecil mana ya, Minggil = Minggir

Dari hasil di atas terlihat bagaimana penguasaan bahasa anak usia dini. Hasil tuturan yang diperoleh anak tidak lengkap sehingga menghasilkan makna yang rancu. Kerancuan ini didapatkan karena anak usia dini masih dalam proses pemenuhan kata dan kalimat dalam bertutur. Tidak berbeda dengan kata yang diucapkan di atas anak usia dini terutama usia 4 tahun masih pelo atau belum sepenuhnya mengusai kata dan ucapan dengan baik, kosa kata yang diucapkan masih simpang siur, walaupun kita mengetahui maknanya.

\subsection{Kaitannya Penyimpangan Tuturan Bahasa dengan Aspek semantik}

Berkaitan dengan semantic, penyimpangan tuturan bahasa anak usia dini dideskripsikan sebagai berikut.

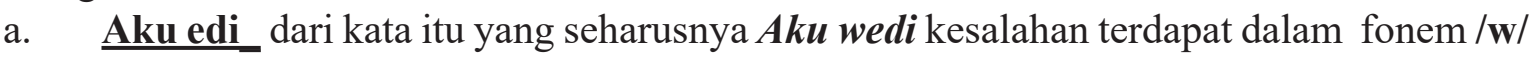
seharusnya diucapkan, tetapi dalam hal ini fonem /w/ dihilangkan dan tidak terucap dalam perkataan. Sehingga makna dari kata Aku edi jadi tidak benar, yang seharusnya Aku Wedi (Saya Takut).

b. Moh'a_dari kata itu yang seharusnya Moh'ah kesalahan terdapat dalam fonem /ah/ seharunya diucapkan, tetapi dalam hal ini fonem /h/ dihilangkan dan tidak terucap dalam perkataan. Sehingga makna dari kata Moh'a jadi tidak benar, yang seharusnya Moh'ah (Tidak Mau).

c. Uan-udan dari kata itu yang seharusnya udan-udan kesalahan terdapat dalam fonem /d/ seharunya diucapkan, tetapi dalam hal ini fonem /d/ dihilangkan dan tidak terucap dalam perkataan. Sehingga makna dari kata Uan-udan jadi tidak benar, yang seharusnya Udan-udan (Hujan-hujan).

d. Alow mandi dari kata itu yang seharusnya Ayo mandi kesalahan terdapat dalam fonem /y / seharunya diucapkan, tetapi dalam hal ini fonem /y dan w/ dihilangkan dan tidak terucap dalam perkataan. Sehingga makna dari kata Alow mandi jadi tidak benar, yang seharusnya Ayo mandi.

e. Byor banyu dari kata itu yang seharusnya Gebyur banyu kesalahan terdapat dalam fonem /g, e, dan u/ seharunya diucapkan, tetapi dalam hal ini fonem /g, e, dan u/ dihilangkan dan tidak terucap dalam perkataan. Sehingga makna dari kata Byor banyu jadi tidak benar, yang seharusnya Gebyur banyu (Siram air).

f. Tak mau_dari kata itu yang seharusnya Gak mau kesalahan terdapat dalam fonem /g dan k/ seharunya diucapkan, tetapi dalam hal ini fonem /g dan $\mathbf{k} /$ dihilangkan dan 
diganti dengan fonem /t dan h/ dalam perkataan. Sehingga makna dari kata Tah mau jadi tidak benar, yang seharusnya Tak mau (Tidak mau).

g. Cemplung ember_dari kata itu yang seharusnya Nyemplung ember kesalahan terdapat dalam fonem /n dan y/ seharunya diucapkan, tetapi dalam hal ini fonem /n dan y/ dihilangkan dan tidak terucap dalam perkataan. Sehingga makna dari kata Cemplung ember jadi tidak benar, yang seharusnya Nyemplung ember (Kedalam ember).

h. Ngopo oe_dari kata itu yang seharusnya Ngopo kowe kesalahan terdapat dalam fonem /k dan w/ seharunya diucapkan, tetapi dalam hal ini fonem /k dan w/ dihilangkan dan tidak terucap dalam perkataan. Sehingga makna dari kata Ngopo oe jadi tidak benar, yang seharusnya Ngopo kowe (Kamu kenapa).

i. Njipok ewe_dari kata itu yang seharusnya Njipok dewe kesalahan terdapat dalam fonem /d/ seharunya diucapkan, tetapi dalam hal ini fonem /d/ dihilangkan dan tidak terucap dalam perkataan. Sehingga makna dari kata Njipok ewe jadi tidak benar, yang seharusnya Njipok dewe (Ambil sendiri).

j. Njibok.ke_dari kata itu yang seharusnya Jipok,ke kesalahan terdapat dalam fonem /n / seharunya di hilangkan, tetapi dalam hal ini fonem /n / dan fonem /b diganti dengan $\mathbf{p}$ / dan diucapkan dalam perkataan adik. Sehingga makna dari kata Njibok.ke jadi rancau dan yang benar seharusnya Jipok,ke (Ambilkan).

k. Anak kecil mama ya_dari kata itu yang seharusnya Anak kecil mana ya kesalahan terdapat dalam fonem /n / seharunya diucapkan, tetapi dalam hal ini fonem /n/ diganti dan terucap dalam perkataan adik. Sehingga makna dari kata Anak kecil mama ya jadi tidak benar, yang seharusnya Anak kecil mana ya.

1. Minggil_dari kata itu yang seharusnya Minggir kesalahan terdapat dalam fonem $/ \mathbf{r} /$ seharunya diucapkan, tetapi dalam hal ini fonem /r/ diganti dan terucap dalam perkataan. Sehingga makna dari kata Minggil jadi tidak benar, yang seharusnya Nyemplung ember (Kedalam ember).

Dari analisis di atas dalam penyimpangan tuturan anak usia dini kajian semantik diketahui ada 12 kesalahan yang didapatkan peneliti. Terdapat kesalahan perubahan bentuk sehingga terjadi perubahan dari makna yang sebenanya.

\section{Simpulan}

Penyimpangan tuturan anak usia 4 tahun yang ditemukan mencakup:

Aku edi_Akuwedi, Moha_Mohah, Uan-udan_udan-udan, Alow mandi_Ayo mandi, Byor banyu_Gebyur banyu, Tah mau_Gak mau, Cemplung ember_Nyemplung ember, Ngopo oe_Ngopo kowe, Njipok ewe_Njipok dewe, Njibok.ke_Jipok,ke, Anak kecil mama ya_Anak kecil mana ya, Minggil_Minggir.

\section{Daftar Pustaka}

Chaer, Abdul. (2003). Psikolinguistik: Kajian Teoretik. Jakarta: Rineka Cipta.

Dardjowidjojo, Soenjono. (2008). Psikolinguistik (Pengantar pemahaman bahasa manusia). Jakarta: Yayasan Obor Indonesia.

Mahsun. (2007). Metode Penelitian Bahasa Tahapan Strategi, Metode, dan Tekniknya. Jakarta: PT Raja Grafindo Persada.

Milawati, Titik. (2009). Peran Pendidikan Anak Usia Dini Dalam Mendukung Perkembangan Bahasa Anak. Skripsi. UMS. 
Moleong, Lexy J. (2005). Metodologi Penelitian Kualitatif. Bandung: PT. Remaja Rosdakarya.

Santoso, Budi. (2009). Pemerolehan Bahasa Anak Usia 3 Tahun Dalam Lingkup Keluarga. Skripsi. UMS.

Ruqayyan. (2008). Pemerolehan Bahasa Anak Usia 4-6 Tahun.

Verhaar. J.M.W. (2008). Asas-asas Linguistik Umum. Yogyakarta: Gadjah Mada Universitiy Press. 